\title{
Emission and oxidation of methane in a meromictic, eutrophic and temperate lake (Dendre, Belgium)
}

\author{
Fleur A.E. Roland ${ }^{a,}{ }^{*}$, François Darchambeau ${ }^{a}$, Cédric Morana ${ }^{\mathrm{b}}$, Steven Bouillon ${ }^{\mathrm{b}}$, \\ Alberto V. Borges ${ }^{a}$ \\ ${ }^{a}$ Chemical Oceanography Unit, Université de Liège, Belgium \\ ${ }^{\mathrm{b}}$ Department of Earth and Environmental Sciences, Katholieke Universiteit Leuven (KU Leuven), Belgium
}

\section{H I G H L I G H T S}

- The studied lake was meromictic and characterized by high methane, nutrients and sulfate concentrations in the water column.

- High aerobic and anaerobic methane oxidation rates were observed in the water column, and were dependent on the season.

- Anaerobic methane oxidation was linked to sulfate reduction, and potentially to nitrate reduction.

- Despite high methane oxidation rates, methane fluxes to the atmosphere were high.

\section{A R T I C L E I N F O}

\section{Article history:}

Received 26 April 2016

Received in revised form

13 October 2016

Accepted 31 October 2016

Available online 9 November 2016

Handling Editor: Y Liu

\section{Keywords:}

Anaerobic methane oxidation

Methane emission

Nitrous oxide

Carbon dioxide

Greenhouse gases

Lake

\begin{abstract}
A B S T R A C T
We sampled the water column of the Dendre stone pit lake (Belgium) in spring, summer, autumn and winter. Depth profiles of several physico-chemical variables, nutrients, dissolved gases $\left(\mathrm{CO}_{2}, \mathrm{CH}_{4}, \mathrm{~N}_{2} \mathrm{O}\right)$, sulfate, sulfide, iron and manganese concentrations and $\delta^{13} \mathrm{C}-\mathrm{CH} 4$ were determined. We performed incubation experiments to quantify $\mathrm{CH}_{4}$ oxidation rates, with a focus on anaerobic $\mathrm{CH}_{4}$ oxidation (AOM), without and with an inhibitor of sulfate reduction (molybdate). The evolution of nitrate and sulfate concentrations during the incubations was monitored. The water column was anoxic below $20 \mathrm{~m}$ throughout the year, and was thermally stratified in summer and autumn. High partial pressure of $\mathrm{CO}_{2}$ and $\mathrm{CH}_{4}$ and high concentrations of ammonium and phosphate were observed in anoxic waters. Important nitrous oxide and nitrate concentration maxima were also observed (up to $440 \mathrm{nmol} \mathrm{L}^{-1}$ and $80 \mu \mathrm{mol} \mathrm{L}{ }^{-1}$, respectively). Vertical profiles of $\delta^{13} \mathrm{C}_{-} \mathrm{CH}_{4}$ unambiguously showed the occurrence of AOM. Important AOM rates (up to $14 \mu \mathrm{mol} \mathrm{L}^{-1} \mathrm{~d}^{-1}$ ) were observed and often co-occurred with nitrate consumption peaks, suggesting the occurrence of AOM coupled with nitrate reduction. AOM coupled with sulfate reduction also occurred, since AOM rates tended to be lower when molybdate was added. $\mathrm{CH}_{4}$ oxidation was mostly aerobic ( $80 \%$ of total oxidation) in spring and winter, and almost exclusively anaerobic in summer and autumn. Despite important $\mathrm{CH}_{4}$ oxidation rates, the estimated $\mathrm{CH}_{4}$ fluxes from the water surface to the atmosphere were high (mean of $732 \mu \mathrm{mol} \mathrm{m} \mathrm{m}^{-2} \mathrm{~d}^{-1}$ in spring, summer and autumn, and up to $12,482 \mu \mathrm{mol} \mathrm{m}{ }^{-2} \mathrm{~d}^{-1}$ in winter).
\end{abstract}

() 2016 Elsevier Ltd. All rights reserved.

\section{Introduction}

Methane $\left(\mathrm{CH}_{4}\right)$ is known to be an important natural and anthropogenic greenhouse gas. $\mathrm{CH}_{4}$ concentrations in the atmosphere have increased dramatically during the 20th century to reach $1850 \mathrm{ppb}$ in 2015, mainly due to human activities

\footnotetext{
* Corresponding author.

E-mail address: froland@doct.ulg.ac.be (F.A.E. Roland).
}

(agriculture, waste disposal and energy extraction and production) (IPCC, 2013; Kirschke et al., 2013; NOAA, 2015). In natural environments, $\mathrm{CH}_{4}$ is anaerobically produced by methanogenic archaea. The total $\mathrm{CH}_{4}$ emission to the atmosphere has been estimated to $540 \mathrm{Tg} \mathrm{CH}_{4} \mathrm{yr}^{-1}$, with a significant contribution from inland waters (Bastviken et al., 2011; Borges et al., 2015; Holgerson and Raymond, 2016). The actual amount of $\mathrm{CH}_{4}$ produced is higher, as a significant fraction of $\mathrm{CH}_{4}$ produced is biologically oxidized before reaching the atmosphere (Bastviken et al., 2002). $\mathrm{CH}_{4}$ oxidation limits the flux of $\mathrm{CH}_{4}$ to the atmosphere, and in inland waters can fuel a 
microbial based food-web (Jones and Grey, 2011).

$\mathrm{CH}_{4}$ oxidation can be performed under both aerobic and anaerobic conditions. It is now commonly assumed that anaerobic $\mathrm{CH}_{4}$ oxidation (AOM) can occur with different final electron acceptors: sulfate $\left(\mathrm{SO}_{4}^{-}\right)$, nitrate $\left(\mathrm{NO}_{3}^{-}\right)$, nitrite $\left(\mathrm{NO}_{2}^{-}\right)$, iron (Fe) and/or manganese (Mn) (Borrel et al., 2011). In seawater, $\mathrm{NO}_{3}^{-}$concentrations are low (usually $<5 \mu \mathrm{mol} \mathrm{L}^{-1}$ ), while $\mathrm{SO}_{4}^{2-}$ concentrations are much higher $\left(\sim 30 \mathrm{mmol} \mathrm{L}^{-1}\right)$. Also, Fe and Mn concentrations (on the order of pmol L ${ }^{-1}$ ) in seawater are negligible compared to $\mathrm{SO}_{4}^{2-}$ concentrations. So, even if denitrification, $\mathrm{Fe}$ - and Mn-reduction are thermodynamically more favorable than $\mathrm{SO}_{4}^{2-}$ reduction, the latter remains the main anaerobic pathway for the degradation of organic matter in the oceans, including the degradation of $\mathrm{CH}_{4}$. While AOM is thus generally coupled to $\mathrm{SO}_{4}^{2-}$ reduction (SDMO) in marine waters and sediments (e.g. Iversen and Jørgensen, 1985; Boetius et al., 2000; Jørgensen et al., 2001), other electron acceptors of AOM have been much less frequently studied in freshwater systems. Due to low the $\mathrm{SO}_{4}^{2-}$ concentrations usually observed in freshwaters environments, AOM is often considered to be negligible compared to aerobic $\mathrm{CH}_{4}$ oxidation (Rudd et al., 1974). However, AOM in freshwaters can also be coupled to $\mathrm{NO}_{2}^{-}$and $\mathrm{NO}_{3}^{-}$ reduction (NDMO), which is thermodynamically much more favorable than SDMO (free Gibs energy of $-928,-765$ and $-17 \mathrm{~kJ} \mathrm{~mol}^{-1} \mathrm{CH}_{4}$, with $\mathrm{NO}_{2}^{-}, \mathrm{NO}_{3}^{-}$and $\mathrm{SO}_{4}^{2-}$ reduction, respectively; Raghoebarsing et al., 2006; Borrel et al., 2011). NDMO has been observed in experimental environments with enrichment of bacteria of interest (e.g. Ettwig et al., 2010; Hu et al., 2011; Haroon et al., 2013), or in sediments cultures with electron acceptors added (e.g. Deutzmann and Schink, 2011; á Norði and Thamdrup, 2014). Despite numerous laboratory observations, the significance of NDMO in natural environments is still largely unknown. Although AOM coupled with Fe- and Mn-reduction (FDMO and MDMO, respectively) has been proposed to occur in various freshwater environments (e.g. ferruginous lakes Matano and Kinneret; Crowe et al., 2011; Sivan et al., 2011; á Norði et al., 2013), to our knowledge no direct rate measurements have been reported in the literature.

In this study, we investigated biogeochemistry of the water column of Dendre stone pit lake (Belgium), a relatively deep (maximum depth $30 \mathrm{~m}$ ) but small $\left(0.032 \mathrm{~km}^{2}\right.$ ) water body in a former limestone quarry, with a focus on quantifying AOM rates and related electron acceptors. This lake was chosen to be an ideal system for studying AOM dynamics because it is known to be meromictic (waters anoxic below $20 \mathrm{~m}$ depth throughout the year) and rich in both organic matter (eutrophic) and sulfide $\left(\mathrm{HS}^{-}\right)$in the anoxic layers. The lake is fed by springs at 7 and $18 \mathrm{~m}$ depth, providing potentially $\mathrm{NO}_{3}^{-}$rich groundwater due to generalized fertilizer contamination that is common in Belgium (SPW-DGO3, 2015). We thus hypothesized that high organic matter supply and bottom layer anoxia sustain high methanogenesis rates, and that $\mathrm{CH}_{4}$ production is removed by SDMO and/or NDMO based on occurrence of high $\mathrm{HS}^{-}$concentrations, and potentially high $\mathrm{NO}_{3}^{-}$ concentrations.

\section{Material and methods}

\subsection{Physico-chemical parameters and sampling}

Sampling in the Dendre stone pit lake $\left(50.6157^{\circ} \mathrm{N}, 3.7949^{\circ} \mathrm{E}\right)$ was carried out in spring (May 2014), summer (August 2014), winter (February 2015) and autumn (October 2015). Depth profiles of dissolved oxygen $\left(\mathrm{O}_{2}\right)$ concentrations, temperature, $\mathrm{pH}$ and specific conductivity were obtained with Yellow Springs Instrument 6600 V2 and Hydrolab DS5 multiparameter probes. The conductivity, $\mathrm{pH}$ and oxygen probes were calibrated the day before each sampling using the protocols and standards recommended by the manufacturer.

\section{2. $\mathrm{CH}_{4}$ oxidation measurements and water column chemical analyses}

At each depth of interest, duplicate samples for $\mathrm{N}_{2} \mathrm{O}$ and $\mathrm{CH}_{4}$ concentration analyses were collected in $60 \mathrm{~mL}$ glass serum bottles from a Niskin bottle through a silicon tube connected to the outlet, left to overflow, poisoned with $200 \mu \mathrm{L}$ of a saturated $\mathrm{HgCl}_{2}$ solution and immediately sealed with butyl stoppers and aluminium caps. Ten other bottles per depth were incubated in the dark and constant temperature (close to in-situ temperature): five of them received $250 \mu \mathrm{l}$ of a solution of molybdate $\left(1 \mathrm{~mol} \mathrm{~L}^{-1}\right.$, hence a final concentration of $4 \mathrm{mmol} \mathrm{L}^{-1}$ ), an inhibitor of sulfur-reducing bacteria and five received no treatment. The biological activity of two incubated bottles (one from each treatment) was stopped at 12,24 , 48,72 and $96 \mathrm{~h}$ by the addition of a saturated $200 \mu \mathrm{l} \mathrm{HgCl} 2$ solution. $\mathrm{CH}_{4}$ and $\mathrm{N}_{2} \mathrm{O}$ concentrations were determined via the headspace equilibration technique ( $20 \mathrm{~mL} \mathrm{~N} \mathrm{~N}_{2}$ headspace in $60 \mathrm{~mL}$ serum bottles) and measured by gas chromatography (GC) with electron capture detection (ECD) for $\mathrm{N}_{2} \mathrm{O}$ and with flame ionization detection (FID) for $\mathrm{CH}_{4}$ (Weiss, 1981). The SRI 8610C GC-ECD-FID was calibrated with certified $\mathrm{CH}_{4}: \mathrm{CO}_{2}: \mathrm{N}_{2} \mathrm{O}: \mathrm{N}_{2}$ mixtures (Air Liquide, Belgium) of 1, 10, 30 and $509 \mathrm{ppm} \mathrm{CH}_{4}$ and of 0.2, 2.0 and $6.0 \mathrm{ppm}$ $\mathrm{N}_{2} \mathrm{O}$. Concentrations were computed using the solubility coefficients of Yamamoto et al. (1976) and Weiss and Price (1980), for $\mathrm{CH}_{4}$ and $\mathrm{N}_{2} \mathrm{O}$, respectively. The precision of measurements was $\pm 3.9 \%$ and $\pm 3.2 \%$ for $\mathrm{CH}_{4}$ and $\mathrm{N}_{2} \mathrm{O}$, respectively. $\mathrm{CH}_{4}$ oxidation rates were calculated based on the decrease of $\mathrm{CH}_{4}$ concentrations in the incubations.

In autumn, triplicate samples for the determination of the partial pressure of $\mathrm{CO}_{2}\left(\mathrm{pCO}_{2}\right)$ were collected in $60 \mathrm{ml}$ plastic syringes directly from the Niskin. The $\mathrm{pCO}_{2}$ was measured with an infra-red gas analyzer (Licor Li-840) after headspace equilibration in the syringe (Abril et al., 2015; Borges et al., 2015). The Li-840 was calibrated with $\mathrm{N}_{2}$ and certified $\mathrm{CO}_{2}: \mathrm{N}_{2}$ mixtures (Air Liquide, Belgium) of $388,813,3788$ and 8300 ppm $\mathrm{CO}_{2}$. The precision of measurements was $\pm 4.1 \%$.

Water extracted for creating the headspace in the serum bottles was used to quantify $\mathrm{SO}_{4}^{2-}, \mathrm{NH}_{4}^{+}, \mathrm{NO}_{2}^{-}, \mathrm{NO}_{3}^{-}, \mathrm{Mn}$ and Fe concentrations. $\mathrm{SO}_{4}^{2-}, \mathrm{NO}_{2}^{-}$and $\mathrm{NH}_{4}^{+}$concentrations were quantified colorimetrically using a 5-cm optical path and a Genesys 10vis spectrophotometer (Thermo Spectronic). $\mathrm{SO}_{4}^{2-}$ concentrations were determined by the nephelometric method according to Rodier et al. (1996), after being precipitated in barium sulfate in an acid environment. $\mathrm{NH}_{4}^{+}$concentrations were determined using the dichloroisocyanurate-salicylate-nitroprussiate colorimetric method (Westwood, 1981), and $\mathrm{NO}_{2}^{-}$concentrations were determined by the sulfanilamide coloration method (APHA, 1998). $\mathrm{NO}_{3}^{-}$ concentrations were determined after vanadium reduction to $\mathrm{NO}_{2}^{-}$ and quantified with a Multiskan Ascent Thermo Scientific multiplates reader (APHA, 1998; Miranda et al., 2001). The detection limits for these methods were $52,0.3,0.15$ and $0.03 \mu \mathrm{mol} \mathrm{L}^{-1}$, for $\mathrm{SO}_{4}^{2-}, \mathrm{NH}_{4}^{+}, \mathrm{NO}_{3}^{-}$and $\mathrm{NO}_{2}^{-}$, respectively.

The samples for total Fe and Mn determination were digested and mineralized in nitric acid, using specific Teflon bombs in a microwave digestion labstation (Ethos D, Milestone Inc.). They were finally diluted into milli-Q water to a volume of $50 \mathrm{ml}$. The total Fe and $\mathrm{Mn}$ concentrations were determined by inductively coupled plasma mass spectrometry (ICP-MS) using dynamic reaction cell (DRC) technology (ICP-MS SCIEX ELAN DRC II, PerkinElmer inc.). Analytical accuracy was verified by a certified reference material (BCR 715, Industrial Effluent Wastewater).

Additional samples to determine vertical profiles of $\mathrm{NO}_{3}^{-}, \mathrm{NH}_{4}^{+}$, 
$\mathrm{NO}_{2}^{-}, \mathrm{PO}_{4}^{3-}$ and $\mathrm{SO}_{4}^{2-}$ concentrations were collected in $50 \mathrm{ml}$ plastic vials after being filtered through a $0.22 \mu \mathrm{m}$ syringe filter, and stored frozen. $\mathrm{NO}_{3}^{-}, \mathrm{NO}_{2}^{-}, \mathrm{NH}_{4}^{+}$and $\mathrm{SO}_{4}^{2-}$ concentrations were determined according to respective methods described above. $\mathrm{PO}_{4}^{3-}$ concentrations were determined colorimetrically with a 5-cm optical path, in a spectrophotometer Thermo Spectronic Genesys 10vis, using the ammonium molybdate-potassium antimonyl tartrate method (APHA, 1998). The detection limit of this method was $0.03 \mu \mathrm{mol} \mathrm{L}^{-1}$.

Samples to determine vertical profiles of $\mathrm{H}_{2} \mathrm{~S}$ concentrations were collected in $60 \mathrm{ml}$ biological oxygen demand bottles after being filtered through a $0.22 \mu \mathrm{m}$ syringe filter, and preserved with $2 \mathrm{ml}$ of $1 \mathrm{~mol} \mathrm{~L}^{-1}$ zinc acetate. Concentrations were determined colorimetrically as described above, using the analytical method described by Cline (1969).

In summer and autumn, an additional $60 \mathrm{~mL}$ glass serum bottle per depth was collected and preserved as described above in order to measure the $\delta^{13} \mathrm{C}$ values of $\mathrm{CH}_{4}\left(\delta^{13} \mathrm{C}-\mathrm{CH}_{4}\right) . \delta^{13} \mathrm{C}_{-} \mathrm{CH}_{4}$ was then determined by a custom developed technique (Morana et al., 2015), whereby a $5 \mathrm{ml}$ helium headspace was first created and $\mathrm{CH}_{4}$ was flushed out through a double-hole needle. $\mathrm{CO}_{2}$ and $\mathrm{H}_{2} \mathrm{O}$ were first removed with a $\mathrm{CO}_{2}$ trap (soda lime) and a water trap (magnesium perchlorate) and then the non-methane volatile organic molecules were trapped and hence removed from the gas stream in a loop immerged in liquid nitrogen. The $\mathrm{CH}_{4}$ was converted to $\mathrm{CO}_{2}$ in an online combustion column similar to that in an Elemental Analyzer. The resulting $\mathrm{CO}_{2}$ was subsequently preconcentrated by immersion of a stainless steel loop in liquid nitrogen passed through a micropacked GC column (HayeSep Q 2 m, 0.75 mm ID; Restek), and finally measured on a Thermo DeltaV Advantage isotope ratio mass spectrometer. $\mathrm{CO}_{2}$ produced by acidification $\left(\mathrm{H}_{3} \mathrm{PO}_{4}\right)$ of certified reference standards for $\delta^{13} \mathrm{C}$ analysis (IAEA-CO1 and LSVEC) was used to calibrate $\delta^{13} \mathrm{C}_{-} \mathrm{CH}_{4}$ data. Reproducibility estimated based on duplicate injection of a selection of samples was typically better than $\pm 0.5 \%$.

\section{3. $\mathrm{CO}_{2}, \mathrm{CH}_{4}$ and $\mathrm{N}_{2} \mathrm{O}$ fluxes calculations}

$\mathrm{CO}_{2}, \mathrm{CH}_{4}$ and $\mathrm{N}_{2} \mathrm{O}$ fluxes to the atmosphere were calculated from the dissolved concentration at $1 \mathrm{~m}$ depth from which was computed the concentration gradient across the air-water interface of $\mathrm{CO}_{2}, \mathrm{CH}_{4}$ and $\mathrm{N}_{2} \mathrm{O}$, and the gas transfer velocity computed from wind speed according to the Cole and Caraco (1998) relationship. A positive flux value corresponds to a net gas transfer from the water to the atmosphere, while a negative flux corresponds to a net gas transfer from the atmosphere to the water. Wind speeds were obtained from the National Centers for Environmental Prediction (NCEP) gridded daily product (grid point: $50.4752^{\circ} \mathrm{N}, 3.7500^{\circ} \mathrm{E}$ ).

\section{Results}

\subsection{Physico-chemical parameters}

The position of thermoclines and chemoclines (specific conductivity and $\mathrm{pH}$ ) strongly differed between seasons (Fig. 1). The water column was well stratified during the sampling in spring, summer and autumn, with thermoclines located in the upper part of the water column (first $10 \mathrm{~m}$ ), while in winter, the water column was mixed from surface to $20 \mathrm{~m}$. Surface temperatures were higher in spring and summer (maximum $18{ }^{\circ} \mathrm{C}$ at $1 \mathrm{~m}$ depth), lowest in winter $\left(5^{\circ} \mathrm{C}\right.$ at $1 \mathrm{~m}$ depth), and intermediate in autumn $\left(14{ }^{\circ} \mathrm{C}\right.$ at $1 \mathrm{~m}$ depth).

During winter, when the water column was almost entirely mixed, the oxycline was located at the bottom of the lake $(20 \mathrm{~m})$ (Fig. 1). However, the oxycline moved upward following the establishment of the thermal stratification in spring, to reach $7 \mathrm{~m}$ and $8.5 \mathrm{~m}$ in summer and autumn, respectively. In spring, summer and winter, significant $\mathrm{N}_{2} \mathrm{O}$ concentration peaks were observed, with a maximum of $440 \mathrm{nmol} \mathrm{L} \mathrm{L}^{-1}$ recorded at $14 \mathrm{~m}$ in summer. In autumn, the distribution of $\mathrm{N}_{2} \mathrm{O}$ was more uniform than during the other seasons, with highest $\mathrm{N}_{2} \mathrm{O}$ concentrations of $35 \mathrm{nmol} \mathrm{L} \mathrm{L}^{-1}$. Except during winter when the peak was observed at the oxicanoxic interface, $\mathrm{N}_{2} \mathrm{O}$ peaks were observed below the oxycline, in anoxic waters during the other three seasons. The $\mathrm{pCO}_{2}$ value in autumn (1560 ppm at $1 \mathrm{~m}$ depth) was well above the atmospheric equilibrium (390 ppm) in oxic surface waters and strongly increased in anoxic waters to reach $\sim 18,000 \mathrm{ppm}$. The $\mathrm{CH}_{4}$ concentrations strongly increased in anoxic waters (up to $618 \mu \mathrm{mol} \mathrm{L}^{-1}$ ) but were also quite important in oxic waters, especially in winter (up to $30 \mu \mathrm{mol} \mathrm{L} \mathrm{L}^{-1}$ at $1 \mathrm{~m}$ depth), and ranged between 0.6 and $1 \mu \mathrm{mol} \mathrm{L}^{-1}$ at $1 \mathrm{~m}$ depth during the other three seasons. During summer, $\delta^{13} \mathrm{C}-\mathrm{CH}_{4}$ were stable in bottom waters $(\sim-75 \%$ o) but started to gradually increase at $10 \mathrm{~m}$, slightly below the base of the oxycline, to reach a maximum of $-45 \%$ between 8.5 and $6 \mathrm{~m}$. In autumn, similarly low $\delta^{13} \mathrm{C}_{-} \mathrm{CH}_{4}(-75 \%)$ were measured in bottom waters but the increase near the oxic-anoxic interface was more abrupt.

Vertical profiles of $\mathrm{NO}_{3}^{-}$and $\mathrm{NO}_{2}^{-}$strongly differed between seasons (Fig. 1). Important $\mathrm{NO}_{3}^{-}$accumulation zones (nitraclines) were observed in both oxic and anoxic waters in spring and at the oxic-anoxic interface in summer. The maximum $\mathrm{NO}_{3}^{-}$concentration was 70 and $30 \mu \mathrm{mol} \mathrm{L} \mathrm{L}^{-1}$ in spring and summer, respectively. In autumn and winter, no nitracline was observed, but instead $\mathrm{NO}_{3}^{-}$ concentrations were quite stable throughout the oxic part of the water column (around 15 and $20 \mu \mathrm{mol} \mathrm{L}^{-1}$ in autumn and winter, respectively), and decreased down to $1 \mu \mathrm{mol} \mathrm{L}^{-1}$ in anoxic waters. Except in autumn where $\mathrm{NO}_{2}^{-}$concentrations remained low (below $1 \mu \mathrm{mol} \mathrm{L}{ }^{-1}$ ) throughout the water column, important $\mathrm{NO}_{2}^{-}$concentrations peaks were also observed. In spring and summer, the maximum peaks of 10 and $20 \mu \mathrm{mol} \mathrm{L}^{-1}$, respectively, were located in anoxic waters. In winter, maximum peak was slightly lower $\left(8 \mu \mathrm{mol} \mathrm{L}{ }^{-1}\right)$ and was located at the oxic-anoxic interface. For each season, deep anoxic waters were rich in $\mathrm{NH}_{4}^{+}$and $\mathrm{PO}_{4}^{3}-$ (up to 190 and $22 \mu \mathrm{mol} \mathrm{L}^{-1}$, respectively), while oxic waters were depleted in these nutrients. However, higher concentrations were observed in oxic waters in winter than in other seasons. Indeed $\mathrm{NH}_{4}^{+}$and $\mathrm{PO}_{4}^{3-}$ concentrations were around 35 and $2 \mu \mathrm{mol} \mathrm{L}^{-1}$, respectively, all along the oxic part of the water column in winter, while $\mathrm{NH}_{4}^{+}$ concentrations were below $5 \mu \mathrm{mol} \mathrm{L}{ }^{-1}$ and $\mathrm{PO}_{4}^{3-}$ concentrations below detection in other seasons.

For each season, total Fe and Mn concentrations were quite high in anoxic waters. The maximum Fe concentration peak of $23 \mu \mathrm{mol} \mathrm{L}{ }^{-1}$ was observed in summer, while the maximum Mn concentration peak of $15 \mu \mathrm{mol} \mathrm{L}{ }^{-1}$ was observed in autumn. $\mathrm{SO}_{4}^{2-}$ concentrations were high all along the vertical profiles (ranging between 354 and $1537 \mu \mathrm{mol} \mathrm{L}^{-1}$ ), but tended to decrease in deep anoxic waters, co-occurring with an increase of $\mathrm{H}_{2} \mathrm{~S}$ concentrations (Fig. 1).

\section{2. $\mathrm{CH}_{4}$ oxidation}

$\mathrm{CH}_{4}$ oxidation was observed during all seasons (Fig. 2). In spring, important rates were observed in both oxic and anoxic waters, without Mo added, up to 4 and $3 \mu \mathrm{mol} \mathrm{L}^{-1} \mathrm{~d}^{-1}$, respectively. In summer, no $\mathrm{CH}_{4}$ oxidation was observed in oxic waters. However, important $\mathrm{CH}_{4}$ oxidation rates were observed in anoxic waters, without and with Mo added. Without Mo added, the two maximum peaks of 9 and $6 \mu \mathrm{mol} \mathrm{L}^{-1} \mathrm{~d}^{-1}$ were observed at 14 and $18 \mathrm{~m}$ depth, respectively. These peaks co-occurred with important $\mathrm{NO}_{3}^{-}$and $\mathrm{SO}_{4}^{2-}$ consumption peaks, up to 2 and $20 \mu \mathrm{mol} \mathrm{L}-1 \mathrm{~d}^{-1}$, respectively. $\mathrm{A} \mathrm{NO}_{2}^{-}$consumption peak of $0.4 \mu \mathrm{mol} \mathrm{L}^{-1} \mathrm{~d}^{-1}$ was also observed at 


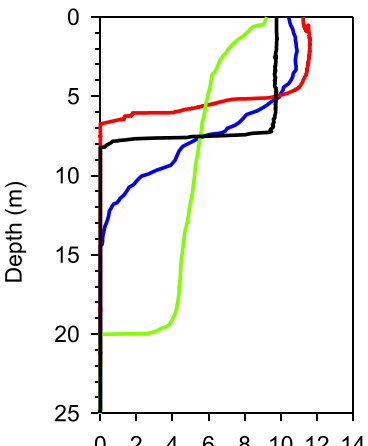

$\begin{array}{llllllll}0 & 2 & 4 & 6 & 8 & 10 & 12 & 14\end{array}$ Dissolved $\mathrm{O}_{2}\left(\mathrm{mg} \mathrm{L}^{-1}\right)$

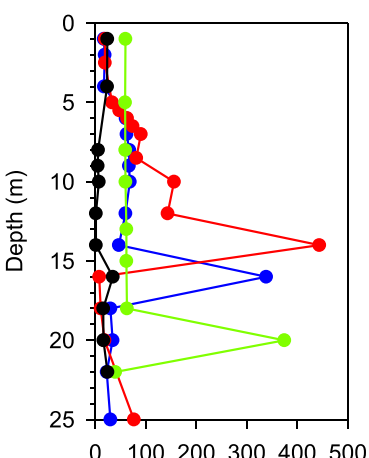

$\mathrm{N}_{2} \mathrm{O}\left(\mathrm{nmol} \mathrm{L}^{-1}\right)$
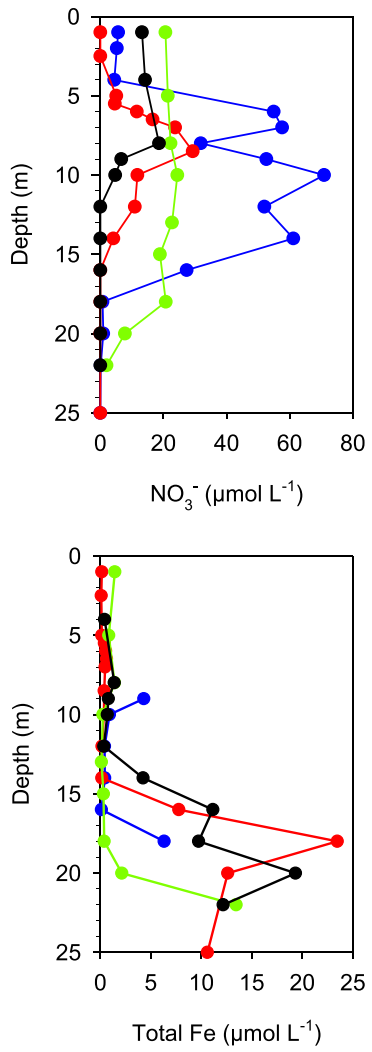

Spring
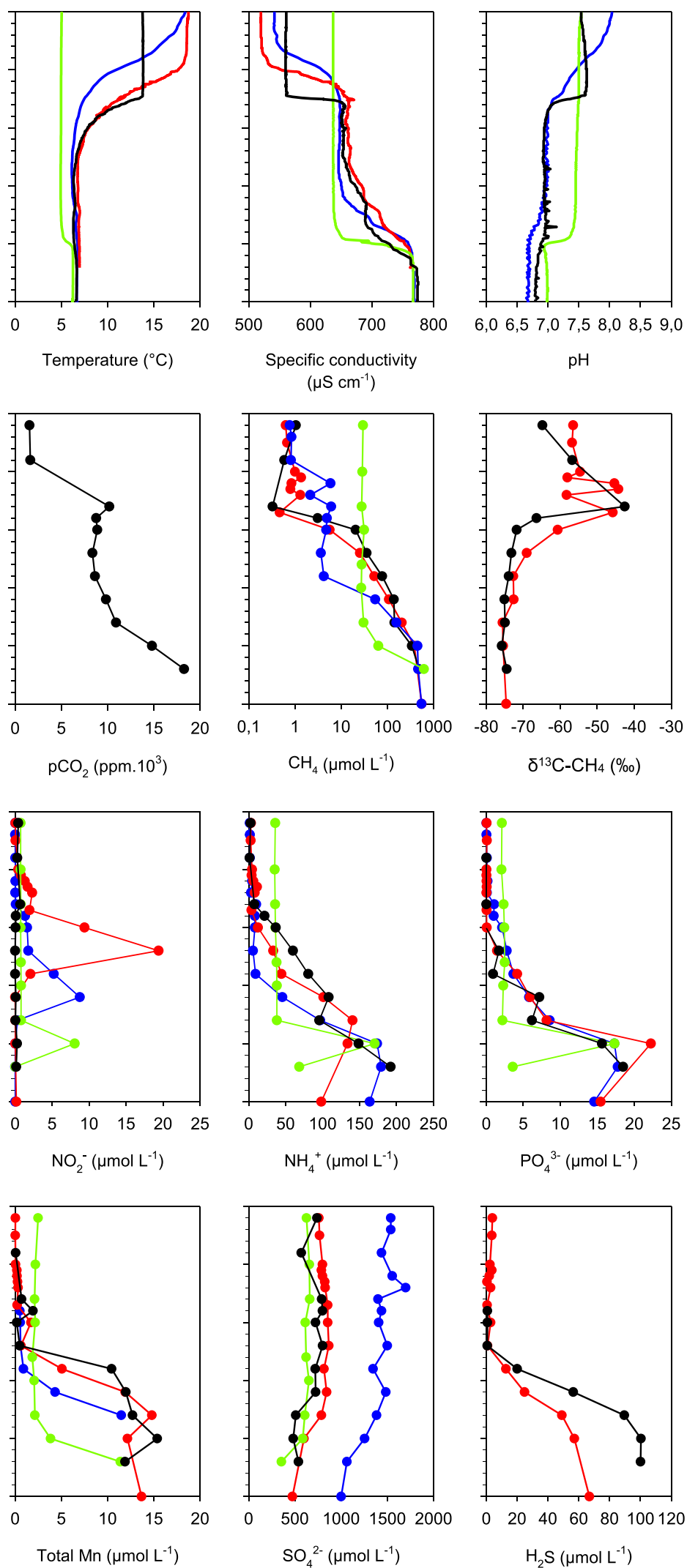

Winter

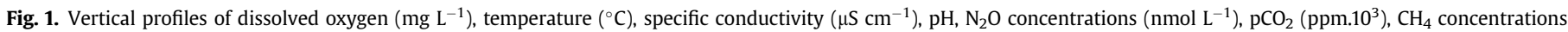

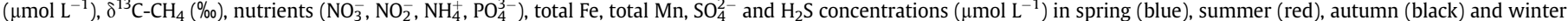

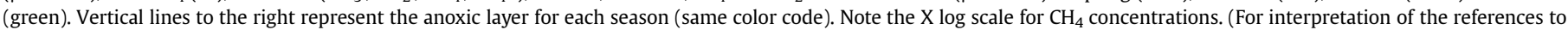
colour in this figure legend, the reader is referred to the web version of this article.) 
$14 \mathrm{~m}$, and another one was also observed in oxic waters. With Mo added, oxidation peaks were observed at the same depths, but rates were lower than without Mo. Important $\mathrm{NO}_{3}^{-}$consumption peaks were also observed at 14 and $18 \mathrm{~m}$, up to $5.5 \mu \mathrm{mol} \mathrm{L}{ }^{-1} \mathrm{~d}^{-1}$, so higher than without Mo added.

In autumn, important oxidation rates were measured throughout the anoxic zone, while no $\mathrm{CH}_{4}$ oxidation was observed in oxic waters. The maximum oxidation rate of $\sim 15 \mu \mathrm{mol} \mathrm{L} \mathrm{L}^{-1} \mathrm{~d}^{-1}$ was observed at $20 \mathrm{~m}$, with and without Mo added. Except at $20 \mathrm{~m}$ where $\mathrm{CH}_{4}$ oxidation rate with Mo was slightly higher than without $\mathrm{Mo}, \mathrm{CH}_{4}$ oxidation rates were always lower with Mo added. Without Mo added, only one peak of $\mathrm{NO}_{3}^{-}$consumption was observed, at $10 \mathrm{~m}$, and thus co-occurred with the first oxidation peak. One $\mathrm{SO}_{4}^{2-}$ consumption peak of $14 \mu \mathrm{mol} \mathrm{L}^{-1} \mathrm{~d}^{-1}$ was observed at $12 \mathrm{~m}$. Below $14 \mathrm{~m}, \mathrm{SO}_{4}^{2-}$ consumption linearly increased. No measurable $\mathrm{NO}_{2}^{-}$consumption was observed. With Mo added, $\mathrm{NO}_{3}^{-}$ consumption was observed just below the oxic-anoxic interface and linearly decreased in anoxic waters, following the same pattern than $\mathrm{CH}_{4}$ oxidation until $12 \mathrm{~m}$ depth. In winter, an aerobic oxidation rate of $1 \mu \mathrm{mol} \mathrm{L} \mathrm{L}^{-1} \mathrm{~d}^{-1}$ was observed at $18 \mathrm{~m}$. Without Mo added, the maximum oxidation peak of $4 \mu \mathrm{mol} \mathrm{L}^{-1} \mathrm{~d}^{-1}$ was observed at the oxic-anoxic interface, and no oxidation was observed below $20 \mathrm{~m}$. A $\mathrm{NO}_{3}^{-}$consumption rate of $3 \mu \mathrm{mol} \mathrm{L}^{-1} \mathrm{~d}^{-1}$ was observed at the same depth, and $\mathrm{SO}_{4}^{2-}$ consumption strongly increased below $20 \mathrm{~m}$ (until $37 \mu \mathrm{mol} \mathrm{L} \mathrm{L}^{-1} \mathrm{~d}^{-1}$ ). No $\mathrm{NO}_{2}^{-}$consumption was observed. With Mo added, no aerobic $\mathrm{CH}_{4}$ oxidation was observed. Also, the $\mathrm{CH}_{4}$ oxidation peak observed at $20 \mathrm{~m}$ was slightly higher $\left(5 \mu \mathrm{mol} \mathrm{L}{ }^{-1}\right.$ $\mathrm{d}^{-1}$ ) and an oxidation peak of $6 \mu \mathrm{mol} \mathrm{L} \mathrm{L}^{-1} \mathrm{~d}^{-1}$ was observed at $22 \mathrm{~m}$ depth. $\mathrm{NO}_{3}^{-}$consumption was lower than without Mo at $20 \mathrm{~m}$ depth, but was higher at $22 \mathrm{~m}$.

\section{3. $\mathrm{CH}_{4}, \mathrm{~N}_{2} \mathrm{O}$ and $\mathrm{CO}_{2}$ fluxes}

$\mathrm{CH}_{4}$ and $\mathrm{N}_{2} \mathrm{O}$ air-water fluxes were estimated during the four seasons, and $\mathrm{CO}_{2}$ air-water flux was estimated for autumn (Table 1 ). The maximum $\mathrm{CH}_{4}$ flux of $12,482 \mu \mathrm{mol} \mathrm{m}^{-2} \mathrm{~d}^{-1}$ was observed in winter, while $\mathrm{CH}_{4}$ fluxes were similar in spring, summer and autumn (mean of $641 \mu \mathrm{mol} \mathrm{m} \mathrm{m}^{-2} \mathrm{~d}^{-1}$ ). $\mathrm{N}_{2} \mathrm{O}$ fluxes were quite constant all along the year (mean of $17 \mu \mathrm{mol} \mathrm{m} \mathrm{m}^{-2} \mathrm{~d}^{-1}$ for summer, autumn and winter), except in spring where the flux was distinctly lower $\left(5 \mu \mathrm{mol} \mathrm{m} \mathrm{m}^{-1}\right)$. The $\mathrm{CO}_{2}$ flux in autumn was $67,000 \mu \mathrm{mol} \mathrm{m}{ }^{-2} \mathrm{~d}^{-1}$.

\section{Discussion}

Physico-chemical parameters (temperature, specific conductivity, $\mathrm{pH}$ and oxygen) showed that the mixed layer depth varied according to the season, but that the deepest part of the water column (below $20 \mathrm{~m}$ ) was anoxic throughout the year. Oxygen concentrations in surface waters were also higher in summer and spring, which can be linked with higher temperatures and irradiance favoring phytoplankton activity, and oxygen production through photosynthesis.

Higher water temperatures also enhance bacterial activity, and denitrification and nitrification, which both produce $\mathrm{N}_{2} \mathrm{O}$, are known to be enhanced when temperature increases (Saad and Conrad, 1993; Van Hulle et al., 2010; Dong et al., 2011). High $\mathrm{N}_{2} \mathrm{O}$ concentrations were observed in summer and spring. In spring, the maximum $\mathrm{N}_{2} \mathrm{O}$ peak was located at $16 \mathrm{~m}$, and co-occurred with the maxima in $\mathrm{NO}_{2}^{-}$concentration and $\mathrm{NO}_{3}^{-}$consumption rate. In summer, the maximum $\mathrm{N}_{2} \mathrm{O}$ peak was observed at $14 \mathrm{~m}$ depth, and also co-occurred with the maximum $\mathrm{NO}_{3}^{-}$consumption rate. Altogether, these observations reflect the occurrence of denitrification in the anoxic water of the lake. Heterotrophic denitrification requires organic matter and $\mathrm{NO}_{3}^{-}$supply. The higher $\mathrm{NO}_{3}^{-}$ concentrations were observed in spring, when nitrification is favored by higher temperatures and abundant $\mathrm{NH}_{4}^{+}$following winter-time mixing.

Denitrification can be heterotrophic, with organic matter as electron donor, but can also be autotrophic with other electron donors. One of these electron donors can be $\mathrm{CH}_{4}$. AOM coupled with $\mathrm{NO}_{3}^{-}$reduction (NDMO) is still poorly understood. However, it is thermodynamically highly favorable (Borrel et al., 2011) and can thus be of great importance in anoxic environments with high $\mathrm{NO}_{3}^{-}$ concentrations. During this study, we investigated $\mathrm{CH}_{4}$ oxidation using two different approaches. The first one was the measurement of the $\delta^{13} \mathrm{C}$ of dissolved $\mathrm{CH}_{4}$ along the depth profile in summer and autumn. While $\delta^{13} \mathrm{C}_{-} \mathrm{CH}_{4}$ values in deep waters were very low $(\sim 65 \%)$, significant increases of $\delta^{13} \mathrm{C}_{-} \mathrm{CH}_{4}$ values were observed between 6 and $8.5 \mathrm{~m}$ depth in summer (at the oxic-anoxic interface and in anoxic waters, until $-44 \%$ ), and at $8 \mathrm{~m}$ depth in autumn (also at the oxic-anoxic interface, until $-43 \%$ ). During microbial processes, isotopic fractionation occurs, since organisms preferentially use the lighter isotopes. Therefore, during $\mathrm{CH}_{4}$ oxidation, bacteria preferentially use ${ }^{12} \mathrm{C}_{-} \mathrm{CH}_{4}$ and the residual $\mathrm{CH}_{4}$ pool is then enriched in ${ }^{13} \mathrm{C}$. For both seasons, the increases of $\delta^{13} \mathrm{C}_{-} \mathrm{CH}_{4}$ values co-occurred with a strong decrease of $\mathrm{CH}_{4}$ concentrations, at the oxic-anoxic interfaces. Hence, the vertical profiles of $\delta^{13} \mathrm{C}_{-} \mathrm{CH}_{4}$ strongly suggest that a large part of $\mathrm{CH}_{4}$ was oxidized within a $5 \mathrm{~m}$ depth interval, in summer and autumn. In autumn, it also cooccurred with a strong increase in $\mathrm{pCO}_{2}$. In autumn and summer, $\delta^{13} \mathrm{C}_{-} \mathrm{CH}_{4}$ decreased from the base of the oxic layer towards surface waters, by $\sim 22$ and $\sim 12 \%$, respectively. Such a decrease cannot be related to exchange with the atmosphere since the atmospheric $\delta^{13} \mathrm{C}_{-} \mathrm{CH}_{4}$ is close to $-47 \%$ (Quay et al., 1999). A possible explanation would be $\mathrm{CH}_{4}$ production in oxic conditions related to primary production by pathways that remain elusive (Tang et al., 2016) as recently reported in several lakes (Grossart et al., 2011; Bogard et al., 2014; Tang et al., 2014). Such an explanation is consistent with the eutrophic nature of the Dendre Lake and should be further investigated in future.

The fraction of the $\mathrm{CH}_{4}$ flux oxidized in a given depth interval was calculated according to the following equation (Coleman et al. 1981):

$\ln (1-f)=\ln \left(\left(\delta^{13} \mathrm{C}-\mathrm{CH}_{4 \mathrm{t}}+1000\right) /\left(\delta^{13} \mathrm{C}-\mathrm{CH}_{4 \mathrm{~b}}+1000\right)\right) /((1 / \alpha)-1)$

where $f$ is the fraction of $\mathrm{CH}_{4}$ oxidized in the depth interval, $\delta^{13} \mathrm{C}$ $\mathrm{CH}_{4 \mathrm{t}}$ and $\delta^{13} \mathrm{C}-\mathrm{CH}_{4 \mathrm{~b}}$ are the $\delta^{13} \mathrm{C}_{-} \mathrm{CH}_{4}$ values at the top and at the bottom of the depth interval, respectively, and $\alpha$ is the isotope fractionation factor.

Coleman et al. (1981) showed that $\alpha$ was dependent on temperature. Bastviken et al. (2002) determined a $\alpha$ of $1.0196 \pm 0.002$ for three Swedish lakes, whose temperature profiles are closer to what we observed. Based on this approach, we computed that in the Dendre Lake in summer, a large fraction (70-73\%) of the upward flux of $\mathrm{CH}_{4}$ was oxidized in a narrow depth interval (between 8.5 and $12 \mathrm{~m}$; anoxic waters). The same observation is made in autumn, since $81-83 \%$ was oxidized between 8 and $10 \mathrm{~m}$ depth (mostly in anoxic waters). This isotopic approach clearly shows the importance of the AOM in the water column of the pit stone lake of the Dendre.

In addition to these indirect estimations of $\mathrm{CH}_{4}$ oxidation, we directly quantified $\mathrm{CH}_{4}$ oxidation in incubation experiments during which the evolution of $\mathrm{CH}_{4}$ concentrations was measured through time. Our incubations focused on AOM and fewer measurements were made in oxic waters. In spring, quite important aerobic $\mathrm{CH}_{4}$ oxidation rates were observed. If we integrate aerobic rates over the oxic water column (from 0 to $13 \mathrm{~m}$ ), we obtain an estimated aerobic oxidation rate of $38 \mu \mathrm{mol} \mathrm{m} \mathrm{m}^{-2} \mathrm{~d}^{-1}$. If we do the same for the anoxic 

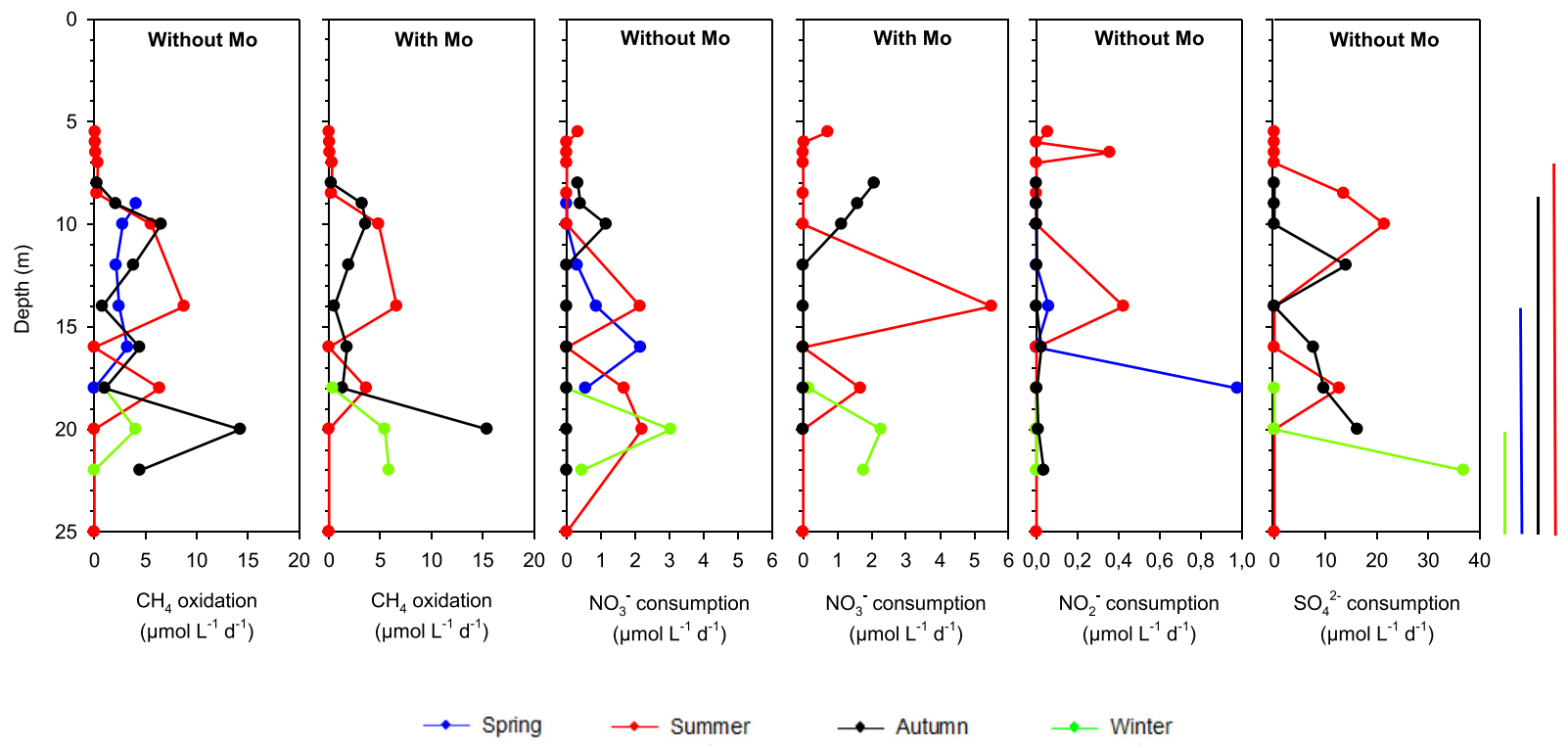

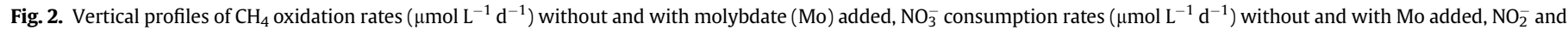

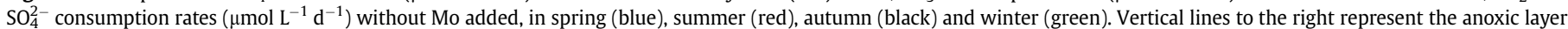
for each season (same color code). (For interpretation of the references to colour in this figure legend, the reader is referred to the web version of this article.)

Table 1

$\mathrm{CH}_{4}, \mathrm{~N}_{2} \mathrm{O}$ and $\mathrm{CO}_{2}$ fluxes $\left(\mu \mathrm{mol} \mathrm{m} \mathrm{m}^{-2} \mathrm{~d}^{-1}\right.$ ) to the atmosphere during the different seasons. $\mathrm{Nd}$ : not determined.

\begin{tabular}{llll}
\hline & $\mathrm{CH}_{4}$ fluxes & $\mathrm{N}_{2} \mathrm{O}$ fluxes & $\mathrm{CO}_{2}$ fluxes \\
\hline Spring & 633 & 5 & $\mathrm{Nd}$ \\
Summer & 1000 & 18 & $\mathrm{Nd}$ \\
Autumn & 564 & 13 & 67,000 \\
Winter & 12,482 & 19 & $\mathrm{Nd}$ \\
\hline
\end{tabular}

water column (from 14 to $25 \mathrm{~m}$ ), only $10 \mu \mathrm{mol} \mathrm{m} \mathrm{m}^{-2} \mathrm{~d}^{-1}$ were anaerobically oxidized. These estimates suggest that aerobic $\mathrm{CH}_{4}$ oxidation was the main pathway of $\mathrm{CH}_{4}$ oxidation in spring, yet AOM still accounted for $21 \%$ of total $\mathrm{CH}_{4}$ oxidation (Table 2). In summer, three measurements of aerobic $\mathrm{CH}_{4}$ oxidation were also made at 5.5, 6 and $6.5 \mathrm{~m}$ depth. Very low $\mathrm{CH}_{4}$ oxidation rates were observed (mean of $0.2 \mu \mathrm{mol} \mathrm{L}^{-1} \mathrm{~d}^{-1}$ ) in oxic waters, while the maximum AOM rate was estimated to $9 \mu \mathrm{mol} \mathrm{L}^{-1} \mathrm{~d}^{-1}$ at $14 \mathrm{~m}$, in accordance with $\delta^{13} \mathrm{C}_{-} \mathrm{CH}_{4}$ data. In summer, AOM was clearly the main pathway of $\mathrm{CH}_{4}$ oxidation, accounting for $99 \%$ of total $\mathrm{CH}_{4}$ oxidation (Table 2). As shown in Fig. 3, aerobic $\mathrm{CH}_{4}$ oxidation highly depends on $\mathrm{CH}_{4}$ concentrations, confirming a strong substrate control of $\mathrm{CH}_{4}$ oxidation (e.g. Guérin and Abril, 2007). $\mathrm{CH}_{4}$ concentrations in oxic waters were higher in spring than in summer, with means of 5 and $1 \mu \mathrm{mol} \mathrm{L}{ }^{-1}$ at depths where oxidation was measured, respectively. These important differences may be explained by the mixed layer depth of the water column. In spring, the water column was anoxic deeper, so $\mathrm{CH}_{4}$ produced in anoxic waters was anaerobically oxidized over a less important depth than in summer, where the water was anoxic at $7 \mathrm{~m}$. Moreover, higher

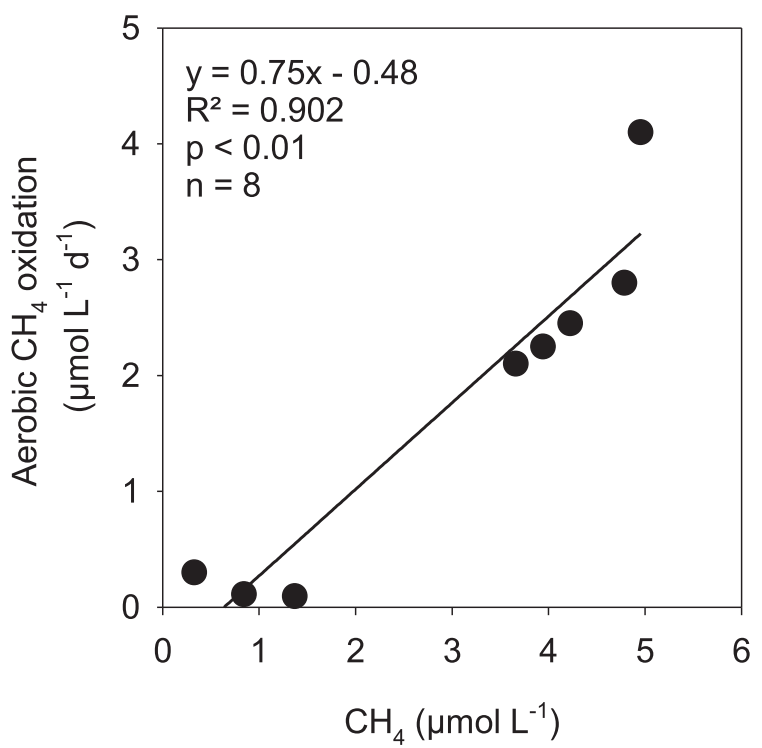

Fig. 3. $\mathrm{CH}_{4}$ concentrations $\left(\mu \mathrm{mol} \mathrm{L} \mathrm{L}^{-1}\right.$ ) in oxic waters compared with aerobic $\mathrm{CH}_{4}$ oxidation rates $\left(\mu \mathrm{mol} \mathrm{L} \mathrm{L}^{-1} \mathrm{~d}^{-1}\right)$, for all seasons.

water temperatures observed in summer might enhance $\mathrm{CH}_{4}$ oxidation. In spring, a greater amount of $\mathrm{CH}_{4}$ could thus reach the oxic waters, explaining higher $\mathrm{CH}_{4}$ concentrations observed, and so higher aerobic $\mathrm{CH}_{4}$ oxidation rates. Fig. 4 a shows the dependence of depth-integrated oxidation rates with the depth of the oxygenated

Table 2

Depth-integrated $\mathrm{CH}_{4}$ oxidation rates $\left(\mu \mathrm{mol} \mathrm{m} \mathrm{m}^{-2} \mathrm{~d}^{-1}\right.$ ) through all the water column, and percentages of aerobic and anaerobic $\mathrm{CH}_{4}$ oxidation, for the four seasons.

\begin{tabular}{|c|c|c|c|}
\hline & Depth-integrated oxidation rates $\left(\mu \mathrm{mol} \mathrm{m}{ }^{-2} \mathrm{~d}^{-1}\right)$ & Aerobic oxidation (\%) & Anaerobic oxidation (\%) \\
\hline Spring & 48 & 79 & 21 \\
\hline Summer & 67 & 1 & 99 \\
\hline Autumn & 70 & 3 & 97 \\
\hline Winter & 27 & 77 & 23 \\
\hline
\end{tabular}


layer. Depth-integrated oxidation rates were lower when the oxycline was located deeper, so in winter and spring, which shows the importance of the anaerobic compartment. Also, as shown by Fig. $4 \mathrm{~b}$, higher $\mathrm{CH}_{4}$ oxidation rates correspond to lower $\mathrm{CH}_{4}$ fluxes, illustrating the importance of $\mathrm{CH}_{4}$ oxidation to prevent $\mathrm{CH}_{4}$ emissions to the atmosphere. In correlation with Fig. 4a and b, Fig. 4c shows that a deeper oxycline is linked to higher $\mathrm{CH}_{4}$ fluxes.

Incubations also revealed important $\mathrm{AOM}$ rates. Because $\mathrm{NO}_{3}^{-}$ and $\mathrm{SO}_{4}^{2-}$ concentrations in the water column were high, we also measured the evolution of these concentrations in the incubations,

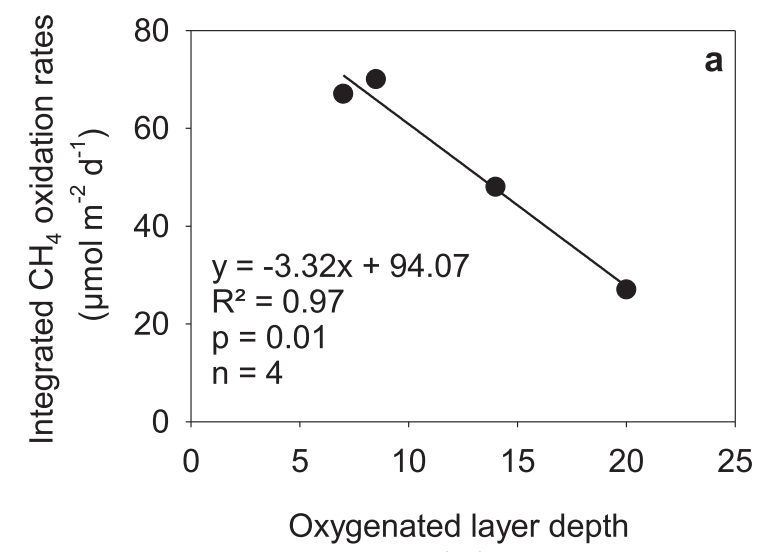

(m)

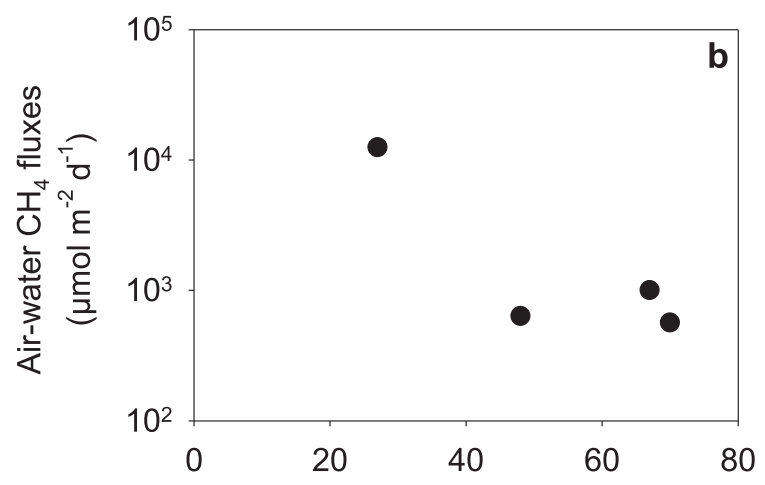

Integrated $\mathrm{CH}_{4}$ oxidation rates $\left(\mu \mathrm{mol} \mathrm{m} \mathrm{m}^{-2} \mathrm{~d}^{-1}\right)$

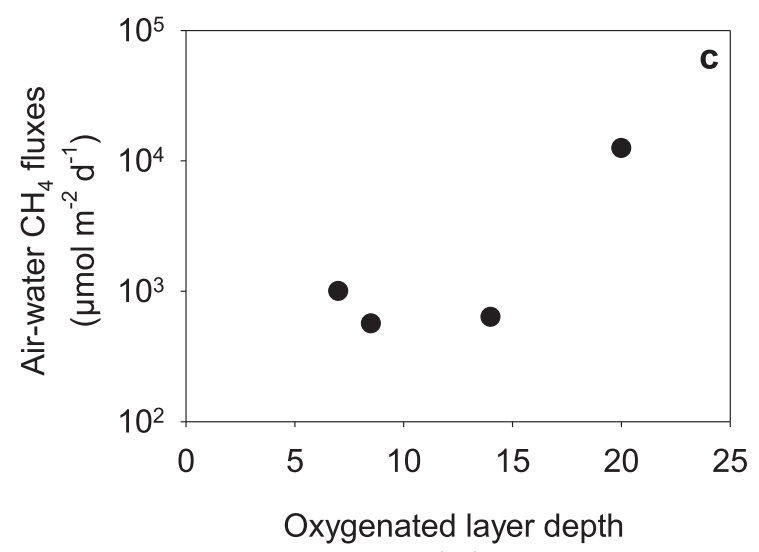

(m)

Fig. 4. (a) Depth-integrated $\mathrm{CH}_{4}$ oxidation rates $\left(\mu \mathrm{mol} \mathrm{m}{ }^{-2} \mathrm{~d}^{-1}\right)$ compared with depth of the oxygenated layer $(\mathrm{m})$ and air-water $\mathrm{CH}_{4}$ fluxes $\left(\mu \mathrm{mol} \mathrm{m} \mathrm{m}^{-2} \mathrm{~d}^{-1}\right)$ compared with (b) depth-integrated $\mathrm{CH}_{4}$ oxidation rates $\left(\mu \mathrm{mol} \mathrm{m} \mathrm{m}^{-2} \mathrm{~d}^{-1}\right)$ and $(\mathbf{c})$ depth of the oxygenated layer $(\mathrm{m})$, for all seasons. Note the $\mathrm{Y} \log$ scales for $\mathrm{b}$ and $\mathrm{c}$. in order to determine if these elements might be AOM electron acceptors. In spring, summer and winter, all the AOM peaks cooccurred with $\mathrm{NO}_{3}^{-}$consumption peaks. In autumn, only the first AOM peak observed at $10 \mathrm{~m}$ depth co-occurred with the peak of $\mathrm{NO}_{3}^{-}$consumption. These results strongly suggest the existence of a coupling between $\mathrm{CH}_{4}$ oxidation and $\mathrm{NO}_{3}^{-}$reduction. However, the observed $\mathrm{NO}_{3}^{-}$consumption rates are not sufficient to be responsible for the observed AOM rates (Fig. 5a). These calculations are based on stoichiometry of the following equation, according to which $8 \mathrm{~mol}$ of $\mathrm{NO}_{3}^{-}$are needed for the oxidation of $5 \mathrm{~mol}$ of $\mathrm{CH}_{4}$ (Raghoebarsing et al., 2006):

$5 \mathrm{CH}_{4}+8 \mathrm{NO}_{3}^{-}+8 \mathrm{H}^{+} \rightarrow 5 \mathrm{CO}_{2}+4 \mathrm{~N}_{2}+14 \mathrm{H}_{2} \mathrm{O}$

The other electron acceptor present at high concentrations is $\mathrm{SO}_{4}^{2-}$. $\mathrm{SO}_{4}^{2-}$ concentrations were high throughout all vertical profiles, and tended to decrease in anoxic waters, when $\mathrm{H}_{2} \mathrm{~S}$ concentrations increased, showing a $\mathrm{SO}_{4}^{2-}$ reduction zone. In our incubations, we observed important $\mathrm{SO}_{4}^{2-}$ consumption rates that can potentially contribute to the $\mathrm{AOM}$. Indeed, $\mathrm{SO}_{4}^{2-}$ consumption rates are sufficient to explain AOM rates observed at some depths. Moreover, when we inhibited sulfate-reducing bacteria by the addition of Mo, we tended to observe lower AOM rates, strongly suggesting a coupling between $\mathrm{AOM}$ and $\mathrm{SO}_{4}^{2-}$ reduction. However, AOM was not fully inhibited, and we can invoke two different reasons to explain this. First, the specific inhibitor used (molybdate) may not be fully efficient, as suggested by Nauhaus et al. (2005) who demonstrated that the two distinct archaeal communities capable of AOM (ANME-I and ANME-II) reacted differently to molybdate, with an incomplete inhibition of ANME-I for the same concentrations of inhibitor. Because we did not perform pyrosequencing analyses in our study, we cannot determine relative community dominance. A second mechanism to explain why AOM was not fully inhibited when molybdate was added, is that SDMO is not the only AOM pathway in the water column of the Dendre stone pit lake, confirming the potential occurrence of NDMO, as described above.

We must note that $\mathrm{AOM}$ rates calculated on the basis of $\mathrm{NO}_{3}^{-}$and $\mathrm{SO}_{4}^{2-}$ consumption rates are potential maximum rates, since we consider here that $\mathrm{NO}_{3}^{-}$and $\mathrm{SO}_{4}^{2-}$ reduction occurs only with $\mathrm{CH}_{4}$ as electron donor, which is unlikely. Heterotrophic denitrification and $\mathrm{SO}_{4}^{2-}$ reduction with organic matter are both more favorable, especially in an environment with high organic matter supply.

We can thus hypothesize that AOM occurred with different electron acceptors in the Dendre stone pit lake. As NDMO is thermodynamically more favorable than SDMO, and as $\mathrm{NO}_{3}^{-}$concentrations are relatively high, we suppose that AOM firstly occurs with $\mathrm{NO}_{3}^{-}$as electron acceptor. When $\mathrm{NO}_{3}^{-}$becomes depleted, $\mathrm{AOM}$ can occur with $\mathrm{SO}_{4}^{2-}$, since SDMO is less favorable but $\mathrm{SO}_{4}^{2-}$ concentrations are higher than $\mathrm{NO}_{3}^{-}$concentrations. Fig. 5b shows $\mathrm{CH}_{4}$ oxidation rates calculated on the basis of $\mathrm{SO}_{4}^{2-}$ consumption rates (according to stoichiometry of equation (2); Borrel et al., 2011) compared with measured $\mathrm{CH}_{4}$ oxidation rates.

$\mathrm{CH}_{4}+\mathrm{SO}_{4}^{2-} \rightarrow \mathrm{HCO}_{3}^{-}+\mathrm{HS}^{-}+\mathrm{H}_{2} \mathrm{O}$

This shows that most of the AOM must be coupled with $\mathrm{SO}_{4}^{2-}$ reduction (data points to the right side of the $1: 1$ line in Fig. $5 \mathrm{~b}$ ), but that $\mathrm{SO}_{4}^{2-}$ is not the only electron acceptor, since some oxidation rates cannot be explained by $\mathrm{SO}_{4}^{2-}$ consumption rates alone (data points to the left side of the 1:1 line in Fig. 5b). We must note that calculated $\mathrm{AOM}$ rates associated with $\mathrm{SO}_{4}^{2-}$ are higher than measured $\mathrm{AOM}$ rates, illustrating that not all the $\mathrm{SO}_{4}^{2-}$ consumption is linked to $\mathrm{CH}_{4}$ oxidation. Also, calculated AOM rates based on $\mathrm{NO}_{3}^{-}$ and $\mathrm{SO}_{4}^{2-}$ consumption rates are potential maximum rates, since in 

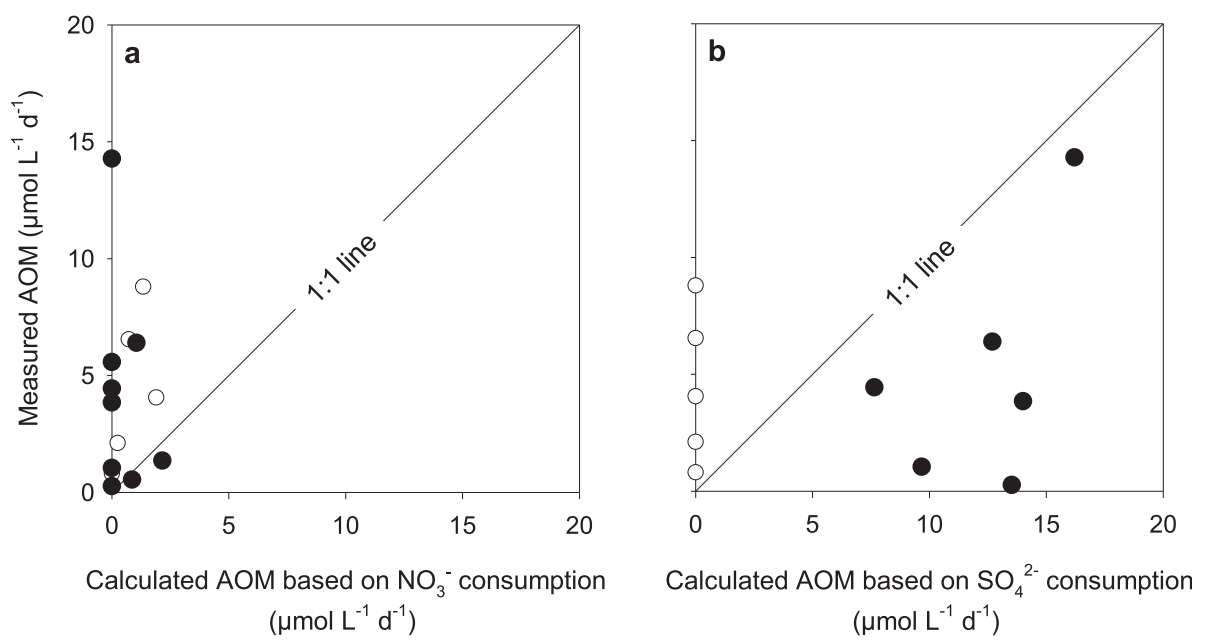

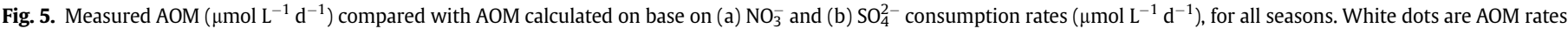
measured with no observation of $\mathrm{SO}_{4}^{2-}$ consumption.

our calculations, we consider that all $\mathrm{NO}_{3}^{-}$and $\mathrm{SO}_{4}^{2-}$ reduction occurs only with $\mathrm{CH}_{4}$ as electron donor. In any case, $\mathrm{NO}_{3}^{-}$can thus be responsible for a part of the AOM not explained by $\mathrm{SO}_{4}^{2-}$ (at the left of the 1:1 line) but it is not sufficient, which means that other electron acceptors must be involved, such as Fe and Mn. Total Fe and Mn concentrations were relatively high in the water column and can thus potentially contribute to AOM. In summer and autumn in particular, higher Fe and $\mathrm{Mn}$ concentration peaks co-occurred with high $\mathrm{CH}_{4}$ oxidation peaks.

Regardless of the electron acceptors, AOM rates in the Dendre stone pit lake were quite high compared to other temperate or boreal lakes reported in literature (Table 3) and must thus contribute to limited atmospheric $\mathrm{CH}_{4}$ fluxes. $\mathrm{CH}_{4}$ concentrations in oxic waters were also high. In winter, in particular, $\mathrm{CH}_{4}$ concentrations in oxic waters were up to $30 \mu \mathrm{mol} \mathrm{L}^{-1}$, which can be linked to the mixing of the water column. The annual average of $\mathrm{CH}_{4}$ concentrations in surface waters was $8.1 \mu \mathrm{mol} \mathrm{L}^{-1}$ which is one order of magnitude higher than the global average of lakes of the same size class $\left(0.01-0.1 \mathrm{~km}^{2}\right)$ of $0.7 \mu \mathrm{mol} \mathrm{L} \mathrm{L}^{-1}$ reported by Holgerson and Raymond (2016). The corresponding median of $\mathrm{CH}_{4}$ emission to the atmosphere $\left(816 \mu \mathrm{mol} \mathrm{m}^{-2} \mathrm{~d}^{-1}\right)$ in the Dendre Lake is also high compared to other lakes globally, since the global median of diffusive $\mathrm{CH}_{4}$ fluxes from lakes at the same latitude reported by Bastviken et al. (2011) is $263 \mu \mathrm{mol} \mathrm{m}{ }^{-2} \mathrm{~d}^{-1}$, while the global flux for lakes of the same size class reported by Holgerson and Raymond (2016) is $279 \mu \mathrm{mol} \mathrm{m}^{-2} \mathrm{~d}^{-1}$.

Bastviken et al. (2011) also reported fluxes due to the emission of $\mathrm{CH}_{4}$ stored in the water column during lake overturn. The median value of these fluxes plus the diffusive fluxes is estimated to

Table 3

Anaerobic $\mathrm{CH}_{4}$ oxidation rates $\left(\mu \mathrm{mol} \mathrm{L}{ }^{-1} \mathrm{~d}^{-1}\right)$ from other lakes in literature.

\begin{tabular}{lll}
\hline Lake & AOM rate & Source \\
\hline Dendre & Seasonal means: 2-5 & This study \\
& Maximum: 15 & \\
Marn (Sweden) & 2.2 & Bastviken et al. (2002) \\
Illersjoen (Sweden) & $1.3-3.0$ & Bastviken et al. (2002) \\
Pavin (France) & 0.4 & Lopes et al. (2011) \\
Mendota (US) & 5.8 & Harrits and Hanson (1980) \\
Big Soda (US) & 0.06 & Iversen et al. (1987) \\
Mono (US) & 0.08 & Oremland et al. (1993) \\
Tanganyika (Africa) & $0.24-1.8$ & Rudd et al. (1974) \\
\hline
\end{tabular}

$1000 \mu \mathrm{mol} \mathrm{m}{ }^{-2} \mathrm{~d}^{-1}$ (Bastviken et al., 2011) that is lower than $\mathrm{CH}_{4}$ emissions estimated in the Dendre stone pit lake in winter $\left(12,482 \mu \mathrm{mol} \mathrm{m}{ }^{-2} \mathrm{~d}^{-1}\right)$. So high $\mathrm{CH}_{4}$ fluxes in winter in the Dendre stone pit lake can be explained by an accumulation of $\mathrm{CH}_{4}$ in anoxic waters during the stratification periods, which are mixed with the oxic waters during lake overturn, as described above. As water temperatures are low, microbial $\mathrm{CH}_{4}$ oxidation in winter is reduced and does not consume the high stock of $\mathrm{CH}_{4}$, which can escape to the atmosphere. High $\mathrm{CH}_{4}$ production in the water column of the Dendre Lake can be explained by a high primary production due to high nutrient availability. Indeed, high DIN $\left(57 \mu \mathrm{mol} \mathrm{L}^{-1}\right)$ and $\mathrm{PO}_{4}^{2-}$ $\left(2 \mu \mathrm{mol} \mathrm{L}{ }^{-1}\right.$ ) concentrations observed in surface waters (at $5 \mathrm{~m}$ ) illustrate the eutrophic status of the lake. This is not surprising considering that this stone pit lake is mainly fed by ground waters, which are enriched in DIN from extensive fertilizer use on cropland (SPW-DGO3, 2015).

The $\mathrm{N}_{2} \mathrm{O}$ fluxes were higher in summer, autumn and winter, with a mean of $17 \mu \mathrm{mol} \mathrm{m}{ }^{-2} \mathrm{~d}^{-1}$. In spring, $\mathrm{N}_{2} \mathrm{O}$ flux was estimated to $5 \mu \mathrm{mol} \mathrm{m} \mathrm{m}^{-2} \mathrm{~d}^{-1}$. Lower $\mathrm{N}_{2} \mathrm{O}$ flux, linked to lower $\mathrm{N}_{2} \mathrm{O}$ concentrations in surface waters observed in spring, might be linked to higher bacterial activity and therefore more efficient denitrification, leading to a stronger $\mathrm{N}_{2} \mathrm{O}$ consumption. Compared with fluxes reported by Huttunen et al. (2003) for five boreal lakes, $\mathrm{N}_{2} \mathrm{O}$ fluxes measured in the Dendre stone pit lake were very high, and no negative flux was observed, suggesting that the water column was a source of $\mathrm{N}_{2} \mathrm{O}$ for the atmosphere all the year. These higher $\mathrm{N}_{2} \mathrm{O}$ emissions can also be related to high DIN concentrations.

In conclusion, this study demonstrates the occurrence of AOM in the water column of a small freshwater body. Results show that AOM occurred with $\mathrm{SO}_{4}^{2-}$ as electron acceptor, but also strongly suggest that AOM also occurred with $\mathrm{NO}_{3}^{-}$reduction. Further studies are nevertheless needed to clearly identify these processes, such as incubations spiked with the addition of the different potential electron acceptors for AOM and description of the microbial community composition. In this study, we also demonstrate that a flooded quarry can be a significant source of atmospheric greenhouse gases. While the majority of eutrophic agriculturally impacted lakes are net $\mathrm{CO}_{2}$ sinks (Balmer and Downing, 2011), we suggest that these systems can be extreme emitters of other potent greenhouse gases such as $\mathrm{CH}_{4}$ and $\mathrm{N}_{2} \mathrm{O}$, in response to nitrogen enrichment and high primary productivity. 


\section{Acknowledgements}

We thank Jean-Pierre Carlier and the members of the diving club "Les Otaries" for their invaluable help in sampling, Professor JeanPierre Thomé (University of Liège, ULg) for access to the multiplate reader, Sandro Petrovic and Marc-Vincent Commarieu (ULg) for help in sampling, Renzo Biondo (ULg) for help in analyses, and two anonymous reviewers for comments and suggestions on the initial submission. A.V.B is a senior research associate to the FNRS. F.A.E.R received a PhD grant from FNRS (Fonds pour la Formation à la Recherche dans l'Industrie et dans l'Agriculture).

\section{References}

á Norði, K., Thamdrup, B., 2014. Nitrate-dependent anaerobic methane oxidation in a freshwater sediment. Geochim. Cosmochim. Acta 132, 141-150.

á Norði, K., Thamdrup, B., Schubert, C.J., 2013. Anaerobic oxidation of methane in an iron- rich Danish freshwater lake sediment. Limnol. Oceanogr. 58, 546-554.

Abril, G., Bouillon, S., Darchambeau, F., Teodoru, C.R., Marwick, T.R., Tamooh, F., Ochieng Omengo, F., Geeraert, N., Deirmendjian, L., Polsenaere, P., 2015. Technical Note: large overestimation of pCO2 calculated from pH and alkalinity in acidic, organic-rich freshwaters. Biogeosciences $12,67-78$.

APHA, 1998. Standard Methods for the Examination of Water and Wastewater. Washington.

Balmer, M.B., Downing, J.A., 2011. Carbon dioxide concentrations in eutrophic lakes: undersaturation implies atmospheric uptake. Inland Waters 1, 125-132.

Bastviken, D., Ejlertsson, J., Tranvik, L., 2002. Measurement of methane oxidation in lakes: a comparison of methods. Environ. Sci. Technol. 36, 3354-3361.

Bastviken, D., Tranvik, L.J., Downing, J.A., Crill, P.M., Enrich-Prast, A., 2011. Freshwater methane emissions offset the continental carbon sink. Science 331, 50.

Boetius, A., Ravenschlag, K., Schubert, C.J., Rickert, D., Widdel, F., Gieseke, A., Amann, R., Jørgensen, B.B., Witte, U., Pfannkuche, O., 2000. A marine microbial consortium apparently mediating anaerobic oxidation of methane. Nature 407, 623-626.

Bogard, M.J., del Giorgio, P.A., Boutet, L., Chaves, M.C.G., Prairie, Y.T., Merante, A., Derry, A.M., 2014. Oxic water column methanogenesis as a major component of aquatic $\mathrm{CH} 4$ fluxes. Nat. Commun. 5.

Borges, A.V., Darchambeau, F., Teodoru, C.R., Marwick, T.R., Tamooh, F., Geeraert, N., Omengo, F.O., Guérin, F., Lambert, T., Morana, C., 2015. Globally significant greenhouse-gas emissions from African inland waters. Nat. Geosci. 8, 637-642.

Borrel, G., Jézéquel, D., Biderre-Petit, C., Morel-Desrosiers, N., Morel, J.-P., Peyret, P., Fonty, G., Lehours, A.-C., 2011. Production and consumption of methane in freshwater lake ecosystems. Res. Microbiol. 162, 832-847.

Cline, J.D., 1969. Spectrophotometric determination of hydrogen sulfide in natural waters. Limnol. Oceanogr. 14, 454-458.

Cole, J.J., Caraco, N.F., 1998. Atmospheric exchange of carbon dioxide in a low-wind oligotrophic lake measured by the addition of SF6. Limnol. Oceanogr. 43, 647-656.

Coleman, D.D., Risatti, J.B., Schoell, M., 1981. Fractionation of carbon and hydrogen isotopes by methane-oxidizing bacteria. Geochim. Cosmochim. Acta 45, 1033-1037.

Crowe, S., Katsev, S., Leslie, K., Sturm, A., Magen, C., Nomosatryo, S., Pack, M., Kessler, J., Reeburgh, W., Roberts, J., 2011. The methane cycle in ferruginous Lake Matano. Geobiology 9, 61-78.

Deutzmann, J.S., Schink, B., 2011. Anaerobic oxidation of methane in sediments of Lake Constance, an oligotrophic freshwater lake. Appl. Environ. Microbiol. 77, 4429-4436.

Dong, L.F., Sobey, M.N., Smith, C., Rusmana, I., Phillips, W., Stott, A., Osborn, A.M., Nedwell, D.B., 2011. Dissimilatory reduction of nitrate to ammonium (DNRA) not denitrification or anammox dominates benthic nitrate reduction in tropical estuaries. Limnol. Oceanogr. 279-291.

Ettwig, K.F., Butler, M.K., Le Paslier, D., Pelletier, E., Mangenot, S., Kuypers, M.M., Schreiber, F., Dutilh, B.E., Zedelius, J., De Beer, D., 2010. Nitrite-driven anaerobic methane oxidation by oxygenic bacteria. Nature 464, 543-548.

Grossart, H.-P., Frindte, K., Dziallas, C., Eckert, W., Tang, K.W., 2011. Microbial methane production in oxygenated water column of an oligotrophic lake. PNAS 108, 19657-19661.

Guérin, F., Abril, G., 2007. Significance of pelagic aerobic methane oxidation in the methane and carbon budget of a tropical reservoir. J. Geophys. Res. Biogeosci. 112.

Haroon, M.F., Hu, S., Shi, Y., Imelfort, M., Keller, J., Hugenholtz, P., Yuan, Z., Tyson, G.W., 2013. Anaerobic oxidation of methane coupled to nitrate reduction in a novel archaeal lineage. Nature 500,567-570.

Harrits, S.M., Hanson, R.S., 1980. Stratification of aerobic methane-oxidizing organisms in lake Mendota, Madison. Wis. Limnol. Oceanogr. 25, 412-421.

Holgerson, M.A., Raymond, P.A., 2016. Large contribution to inland water CO2 and CH4 emissions from very small ponds. Nat. Geosci. 9, 222-226.

Hu, S., Zeng, R.J., Keller, J., Lant, P.A., Yuan, Z., 2011. Effect of nitrate and nitrite on the selection of microorganisms in the denitrifying anaerobic methane oxidation process. Environ. Microbiol. Rep. 3, 315-319.
Huttunen, J.T., Alm, J., Liikanen, A., Juutinen, S., Larmola, T., Hammar, T., Silvola, J., Martikainen, P.J., 2003. Fluxes of methane, carbon dioxide and nitrous oxide in boreal lakes and potential anthropogenic effects on the aquatic greenhouse gas emissions. Chemosphere 52, 609-621.

IPCC, 2013. Climate Change 2013: the Physical Science Basis. Contribution of Working Group I to the Fifth Assessment Report of the Intergovernmental Panel on Climate Change. Cambridge University Press, Cambridge, United Kingdom and New York, NY, USA.

Iversen, N., Jørgensen, B., 1985. Anaerobic methane oxidation rates at the sulfatemethane transition in marine sediments from Kattegat and Skagerrak (Denmark). Limnol. Oceanogr. 30, 944-955.

Iversen, N., Oremland, R.S., Klug, M.J., 1987. Big Soda Lake (Nevada). 3. Pelagic methanogenesis and anaerobic methane oxidation. Limnol. Oceanogr. 32, 804-814.

Jones, R.I., Grey, J., 2011. Biogenic methane in freshwater food webs. Freshw. Biol. 56, $213-229$.

Jørgensen, B.B., Weber, A., Zopfi, J., 2001. Sulfate reduction and anaerobic methane oxidation in Black Sea sediments. Deep-Sea Res. Pt. I 48, 2097-2120.

Kirschke, S., Bousquet, P., Ciais, P., Saunois, M., Canadell, J.G., Dlugokencky, E.J., Bergamaschi, P., Bergmann, D., Blake, D.R., Bruhwiler, L., Cameron-Smith, P., Castaldi, S., Chevallier, F., Feng, L., Fraser, A., Heimann, M., Hodson, E.L., Houweling, S., Josse, B., Fraser, P.J., Krummel, P.B., Lamarque, J.-F., Langenfelds, R.L., Le Quere, C., Naik, V., O'Doherty, S., Palmer, P.I., Pison, I., Plummer, D., Poulter, B., Prinn, R.G., Rigby, M., Ringeval, B., Santini, M., Schmidt, M., Shindell, D.T., Simpson, I.J., Spahni, R., Steele, L.P., Strode, S.A. Sudo, K., Szopa, S., van der Werf, G.R., Voulgarakis, A., van Weele, M., Weiss, R.F., Williams, J.E., Zeng, G., 2013. Three decades of global methane sources and sinks. Nat. Geosci. 6, 813-823.

Lopes, F., Viollier, E., Thiam, A., Michard, G., Abril, G., Groleau, A., Prévot, F., Carrias, J.-F., Albéric, P., Jézéquel, D., 2011. Biogeochemical modelling of anaerobic vs. aerobic methane oxidation in a meromictic crater lake (Lake Pavin, France). Appl. Geochem 26, 1919-1932.

Miranda, K.M., Espey, M.G., Wink, D.A., 2001. A rapid, simple spectrophotometric method for simultaneous detection of nitrate and nitrite. Nitric Oxide-Biol. Ch $5,62-71$.

Morana, C., Borges, A.V., Roland, F.A.E., Darchambeau, F., Descy, J.P., Bouillon, S., 2015. Methanotrophy within the water column of a large meromictic tropical lake (Lake Kivu, East Africa). Biogeosciences 12, 2077-2088.

Nauhaus, K., Treude, T., Boetius, A., Krüger, M., 2005. Environmental regulation of the anaerobic oxidation of methane: a comparison of ANME-I and ANME-II communities. Environ. Microbiol. 7, 98-106.

NOAA, 2015. The NOAA Annual Greenhouse Gas Index (AGGI). NOAA Earth System Research Laboratory, Broadway.

Oremland, R.S., Miller, L.G., Colbertson, C.W., Robinson, S., Smith, R.L., Lovley, D. Whiticar, M.J., King, G.M., Kiene, R.P., Iversen, N., 1993. Aspects of the Biogeochemistry of Methane in Mono Lake and the Mono Basin of California. Biogeochemistry of Global Change. Springer, pp. 704-741.

Quay, P., Stutsman, J., Wilbur, D., Snover, A., Dlugokencky, E., Brown, T., 1999. The isotopic composition of atmospheric methane. Glob. Biogeochem. Cy. 13, $445-461$.

Raghoebarsing, A.A., Pol, A., Van de Pas-Schoonen, K.T., Smolders, A.J., Ettwig, K.F. Rijpstra, W.I.C., Schouten, S., Damsté, J.S.S., den Camp, H.J.O., Jetten, M.S., 2006 A microbial consortium couples anaerobic methane oxidation to denitrification. Nature 440, 918-921.

Rodier, J., Bazin, C., Broutin, J., Chambon, P., Champsaur, H., Rodi, L., 1996. L'Analyse de l'Eau (8ème édn). Dunod, Paris: France.

Rudd, J.W.M., Hamilton, R.D., Campbell, N.E.R., 1974. Measurement of microbia oxidation of methane in lake water. Limnol. Oceanogr. 19, 519-524.

Saad, O.A.L.O., Conrad, R., 1993. Temperature dependence of nitrification, denitrification, and turnover of nitric oxide in different soils. Biol. Fert. Soils 15, 21-27.

Sivan, O., Adler, M., Pearson, A., Gelman, F., Bar-Or, I., John, S.G., Eckert, W., 2011. Geochemical evidence for iron-mediated anaerobic oxidation of methane. Limnol. Oceanogr. 56, 1536-1544.

SPW-DGO3, 2015. Etat des nappes d'eau souterraine de Wallonie. Belgique.

Tang, K.W., McGinnis, D.F., Frindte, K., Brüchert, V., Grossart, H.-P., 2014. Paradox reconsidered: methane oversaturation in well-oxygenated lake waters. Limnol. Oceanogr. 59, 275-284.

Tang, K.W., McGinnis, D.F., Ionescu, D., Grossart, H.-P., 2016. Methane production in oxic lake waters potentially increases aquatic methane flux to air. Environ. Sci. Technol. Lett. 3, 227-233.

Van Hulle, S.W.H., Vandeweyer, H.J.P., Meesschaert, B.D., Vanrolleghem, P.A., Dejans, P., Dumoulin, A., 2010. Engineering aspects and practical application of autotrophic nitrogen removal from nitrogen rich streams. Chem. Eng. J. 162, $1-20$.

Weiss, R.F., 1981. Determinations of carbon dioxide and methane by dual catalyst flame ionization chromatography and nitrous oxide by electron capture chromatography. J. Chromatogr. Sci. 19, 611-616.

Weiss, R.F., Price, B.A., 1980. Nitrous oxide solubility in water and seawater. Mar Chem. 8, 347-359.

Westwood, D., 1981. Ammonia in Waters. Methods for the Examination of Waters and Associated Materials. HMSO, London, United Kingdom.

Yamamoto, S., Alcauskas, J.B., Crozier, T.E., 1976. Solubility of methane in distilled water and seawater. J. Chem. Eng. Data 21, 78-80. 